\title{
1. De Viti de Marco vs. Ricardo on public debt: self-extinction or default?
}

\author{
Giuseppe Eusepi and Richard E. Wagner
}

\section{INTRODUCTION}

This chapter provides new insight into Antonio de Viti de Marco's (1936) interpretation of David Ricardo's (1817) equivalence theorem, for which Robert Barro (1974) provides a modern restatement, holding that an extraordinary tax and a public loan are equivalent. There is a superficial similarity between the two theorists. At a deeper level of examination, however, the two theorists diverge sharply. In this respect, de Viti and Ricardo resemble the two parabolas $\mathrm{X}^{2}$ and $-\mathrm{X}^{2}$ : they share a common origin but point their analytical attention in opposing directions. Ricardo reasoned in terms of macro aggregates and then reduced that aggregate to a representative individual. Within this framework, public debt must be self-extinguishing because Ricardo's representative individual framework prevents an individual from defaulting on himself. The self-extinction of public debt is a built-in feature of Ricardo's purely abstract model where what was in play was a simple matter of double-entry accounting, in which case an extraordinary tax and a public loan must have equivalent present value.

While de Viti accepted Ricardo's aggregative arithmetic, he regarded this arithmetic as a truism that obscured the individual actions and interactions that were occurring at the micro level of action. What de Viti called the cooperative state was but one possible model of political economy that provided more of an analytical foil than a reasonable theory of politicaleconomic experience, as Michele Giuranno and Manuela Mosca (2016) explain in their extensive examination of de Viti's concern with developing realistic models of the state. For de Viti, the cooperative state was actually an anti-political model in the spirit of Carl Schmitt's (1932) recognition of the autonomy of the political in society. It is the state reduced wholly to contractual obligation under voluntarism. In this limiting case, public debt 
must be self-extinguishing because no one would agree to extend credit to someone without believing that the resulting obligation will be met. At the level of ex ante expectation, public debt must be self-extinguishing under an institutional regime within which all political action is voluntary. To be sure, one might doubt whether political action can ever be made wholly voluntary, in which case self-extinction gives way to some form of default, not as reflected in aggregate variables but as reflected in individual expectations.

It is at this point of individual expectation that de Viti's analysis diverges sharply from Ricardo's because de Viti recognized that aggregate variables are derived from individual interactions that themselves occur within particular institutional settings that channel power. Hence, public debt will be self-extinguishing only as an extreme limiting case. Where self-extinction of public debt was built into Ricardo's model, it was only one possibility within de Viti's model. A model that assumes that all collective action is genuinely contractual will necessarily entail self-extinction of public debt. But this outcome is an artifact of a particular model and not a general feature of reality. Even with a cooperative state model, self-extinction can fail if some share of the debt is held externally. In this situation, members of the issuing polity can secure positive wealth gains by defaulting on their obligations to outsiders. To be sure, default would undermine the reputation of the defaulting polity, and so could not serve as a continuing policy. All the same, it is worth noting that a gain that lasts but seven years is worth about half as much as one that would last forever if people discount the future at 10 percent. In other words, the prospect of foreclosing longterm options might be embraced if the short-term gains of doing so are sufficiently attractive. Only if the loan must be re-purchased by domestic taxpayers can default be precluded by theoretical construction. ${ }^{1}$ Otherwise, the prospect of default depends on institutionally governed relationships among relevant participants.

Once it is recognized that democratic polities are never fully cooperative, there are numerous paths along which public debt can be repudiated in whole or in part. For instance, the use of debt to transfer cost from some members of a polity to other members is a form of repudiation when judged from a contractual perspective. Repudiation can thus arise even if all debt is held internally, though the presence of external debt widens the possibilities for repudiation. Once we recognize, as de Viti recognized, that democratic states are only incompletely cooperative states, debt will not be extinguished as the contractual framework envisions. ${ }^{2}$ Once it is

See De Viti (1893).

It goes without saying that this is in a democratic state, not in a cooperative state where defaulting is a clearing transaction only. 
recognized that democratic governments are never fully cooperative, public debt becomes a means by which winning groups within the polity transfer wealth from losing groups.

\section{DE VITI VS. RICARDO ON THE EQUIVALENCE BETWEEN TAXES AND LOANS}

From a superficial or aggregative point of view, de Viti and Ricardo make similar, if not identical claims about the equivalence between taxes and loans. The equivalence is an accounting identity from the perspective of double-entry accounting applied to some closed entity that contains all of the participants in the public debt transaction. If debt transactions are wholly contractual, as they are within the presuppositions of the cooperative state, public debt leaves all individual balance sheets unaffected. Public debt is not a source of net wealth to any person within the rubric of de Viti's cooperative state. It is easy to see how de Viti could have been described as the 'Italian Ricardo'. For Ricardo, equivalence was treated as an accounting identity, as Robert Barro (1974) explains in his well-cited explanation of how the issuance of government bonds does not increase aggregate net worth, and with Barro's treatment of Ricardo standing in sharp contrast to Keynesian-like claims on behalf of the stabilizing properties of fiscal policy. Subsequent to Barro, a considerable body of literature has arisen over Barro's Ricardian implication about the impotence of fiscal policy. Ricardo is an archetypical macro theorist who reasons in terms of global aggregates, leaving out of analytical sight the micro details from which those aggregates are constituted.

Where Ricardo, like most macro theorists today, theorized in top-down fashion whereby changes in macro variables caused micro variables to take on the necessary accommodating values, de Viti was a quintessential micro theorist. For de Viti, aggregate variables were nothing but statistical reflections of underlying micro-level interaction. De Viti recognized that circumstances could exist wherein an extraordinary tax would be equivalent to a public loan, but this equivalence was not a mere accounting identity. To the contrary, it was a working property of a particular set of institutional arrangements. In particular, these were the institutional arrangements associated with de Viti's model of the cooperative state. With respect to the actual conduct of economic life, de Viti (1893) is manifestly anti-Ricardian, as is Benvenuto Griziotti (1917). ${ }^{3}$ It was Buchanan (1958,

3 For a general view, see Eusepi (1989). 
$1960,1976)$ who tried to incorporate de Viti's analysis on public debt into the specific doctrinal body of the Italian School of Public Finance, and distinguished the Italian tradition from the Anglo-Saxon tradition on which the Ricardian equivalence proposition rested.

It is a matter of simple arithmetic to affirm Barro's (1974) claim that the issuance of public debt does not increase aggregate net worth. Suppose some volume of taxation is replaced by an equal amount of public debt, as an act of Keynesian-like fiscal policy. The decrease in taxation is, taken by itself, an increase in disposable income. The concomitant issuance of government bonds, however, creates an obligation to increase taxes in future years to amortize the debt. At the time the debt is issued, an aggregate balance sheet would show no change in net worth. The asset labeled 'disposable income' is increased, but that increase is offset by an increase in the liability denoted 'taxes payable'. As a matter of the simple arithmetic of double-entry accounting, an increase in public debt cannot increase aggregate net worth. Such an increase, however, can increase net worth for some people while simultaneously decreasing it for other people, with this redistribution having much to do with the creation of public debt. The validity of this point requires de Viti's recognition to be embraced that macro-level conditions are generated through micro-level interaction, and with there being numerous distinct forms that such interaction can take.

Despite Buchanan's emphasis on the central role that public expenditure had in de Viti's analysis, subsequent Italian scholars mostly failed to extend and amplify de Viti's scheme of non-Ricardian analysis, and embraced instead the Ricardian scheme of analysis whereby public debt raises macro questions that can be addressed without addressing any underlying micro-level questions. For de Viti, however, macro-level statements must be reconciled with micro-level actions and interactions. In making this reconciliation, de Viti recognized the erroneous character of Ricardo's intertemporal comparison that led Ricardo to conclude that an extraordinary tax and public loan were necessarily equivalent. De Viti recognized that the two could be equivalent, but there was no necessity that they actually be equivalent. Ricardo's analysis was a simple exercise in macro aggregation. In contrast, de Viti recognized that macro-level variables were emergent by-products of micro-level interactions that were governed by some institutional framework that structured those interactions. To de Viti, equivalence is a possibility that would arise only if public and private allocations were equally efficient at the relevant margins of activity. According to de Viti, the cost has to be analyzed by comparing present and future utility and 'by reasoning on the difference'. This difference, de Viti wrote, 'is the new premise of a new problem so that any reasoning dealing with contributed goods only, without considering public goods that are 
provided or dealing with the utility of public goods without referring to costs, would be erroneous' (1898, p. 114). It is precisely with making this mistake that de Viti charges Ricardo. ${ }^{4}$

To avoid Ricardo's mistake required de Viti to develop an analytical framework that enabled public debt to emerge within some institutionally reasonable and plausible system of political economy. De Viti recognized that his purely cooperative state was a limiting idealization that was never fully realized in democratic political systems. On this point, it is perhaps also worth mentioning that de Viti served some 20 years as a member of the Italian Parliament, so his work was informed by some conjunction of theoretical and practical interests. Michele Giuranno and Manuela Mosca (2016) present a careful examination of de Viti's political realism in this respect, which shows that de Viti never confused his limiting ideal of a cooperative state with actual democracies. In this respect, de Viti's (1930) collection of essays characterizing 30 years of political struggles shows clearly that the cooperative state might stand as some model appropriate for the end of history but it was not a reliable guide to understanding the course of historical life.

\section{ACTUAL DEMOCRACY AS SEMI-COOPERATIVE STATE}

While de Viti articulated a model of a cooperative state, his interest in doing so created a useful framework for thinking about collective activity in an explanatory manner. In this respect, starting from his first work in public finance in 1888, de Viti sought to place public finance on an explanatory footing, in sharp contrast to the strongly normative or tutorial position it had in the hands of most theorists. De Viti's model of the cooperative state brought forward such commonalities of economic organization through markets as utility, demand, cost, and organization so as to bring those commonalities to bear on the economic organization of collective activity. De Viti (1930) was also well aware that actual democratic arrangements bore but an imperfect resemblance to his idealized model of the cooperative state.

In actual democratic settings there is no necessity that public debt be self-extinguishing. It must be self-extinguishing within the framework of the cooperative state, for the state within that framework had the same properties of consensual interaction among participants as did a market

4 The critique that de Viti addresses to Ricardo regarding his exclusion of benefits can be extended to the Keynesian theory on costs. 
economy grounded in private property and freedom of contract. Within a market economy, personal debt is self-extinguishing, which means that personal debt is not an instrument by which a borrower can increase his or her net worth, as against postponing redemption of some liabilities, and paying for that postponement by paying interest. An individual might refuse to discharge a debt, thereby transferring wealth from lender to borrower to the extent that refusal is successful. Within actual democratic polities there are numerous ways that default and repudiation can be baked into the fiscal cake, so to speak. Each of these ways involves one margin or another along which the ideal of the wholly cooperative state is violated, in which case public debt can become a political instrument that allows friends to be rewarded and enemies punished, along the lines that Carl Schmitt (1932) set forth in his analysis of the autonomy of the political in society. This can happen both with externally held debt and with internally held debt.

\section{COOPERATIVE STATE DEFAULT WITH EXTERNAL DEBT}

By de Viti's contractual construction of the cooperative state, public debt is self-extinguishing; however, this self-extinguishing feature is a product of de Viti's presumption that the transactions that generate public debt are confined within the state. De Viti's pure cooperative model is an in vitro construction consisting of a small closed economy with a small - although not minimalist - government. ${ }^{5}$ The extent of politically organized activity depends on the relative efficiency of public expenditures and private expenditures on a project-by-project basis. Under these restrictive conditions, resorting to a public loan is to treat the loan as if it were an intertemporal exchange where the creation of debt is a transaction whereby lenders pay current taxes for borrowers, and with those borrowers discharging their obligations according to the terms of the debt contract. In de Viti's logic, the public loan is a clearing transaction between each member of the cooperative qua producer and each single saver qua consumer. In the end, the public loan is a general clearing account where the net value of both individual and aggregate transactions is zero.

This situation changes once foreigners can buy debt instruments on credit markets. Public debt is no longer confined to the members of a state that issues the debt, as some instruments of public debt can be held by

5 On the minimalist government see Roth (2002). 
foreigners. The opening of the credit market to foreigners can undermine the cooperative state by changing the political dynamics inside the issuing state. No longer does public debt entail the state acting as an intermediary between borrowers and lenders within the state. A foreign subscriber to public debt can do so as an investor, reflecting the reach of an international market in credit instruments. The existence of such a market, however, can bring about the end of the cooperative state because both the automatic self-extinction of public debt and the equivalence between debt financing and tax financing are undermined by the presence of an international credit market which opens a channel of debt default even if the institutional arrangement of the state promotes internal consensus.

To be sure, de Viti seems to follow a different path, along which he tries to extend his cooperative model made up of three individuals with the same income but coming from different sources (liquid assets, landowners and professionals) to the case of external debt. A brief outline of this model would be appropriate before raising doubt on its feasibility. Let's give an Italian flavor to the narrative and assume that Primus, Secundus and Tertius are a landowner, a capitalist and a professional respectively. Let's also assume that Primus and Tertius are taxpayers of the cooperative state and Secundus, who is a foreigner and bond subscriber, is a capitalist who holds his assets in liquid form. De Viti claims that there is no difference between two distinct situations. In the closed credit market, the capitalist lends his money to Primus and Tertius to pay their tax bills, with Secundus paying his tax bill directly to exemplify the equivalence between an extraordinary tax and a set of private loans. In the open credit market, Secundus buys government-issued bonds, with the state using the proceeds to finance state activity in lieu of tax payments by Primus and Tertius.

However ingenious this theoretical construction is, it leaves us puzzled. While in the case of an internal debt Secundus pays his tax bill directly, in the open market where Secundus is simply a subscriber and not a taxpayer, the equivalence between tax and debt vanishes. When the capitalist is a foreigner, more complex mechanisms come into play. Unlike the pure cooperative model, in this case there is a shortage of internal liquidity since the government would be simply unable to levy an extraordinary tax on foreigners. The equivalence between tax and debt requires that there be a genuine choice possible between the two options. This situation, however, is not consistent with market transactions where cooperative relationships are absent. It is precisely the fact that Secundus is not a member of the cooperative polity that renders invalid the identity between producer and consumer on which the cooperative model hinges. As is well known, the non-coincidence between producer and consumer is the presupposition or precondition for the exchange and, hence, also for the exchange 
between those who lend and those who borrow. This precondition of exchange is not an attribute of the cooperative state. It is rather proper for a competitive state where incomes are not homogeneous, either intra- or inter-generationally.

In the democratic state, government is still an intermediary, as it was in de Viti's cooperative state, save that producers and consumers are different individuals and so are taxpayers and bond subscribers. Hence, when one moves from a single country setting to an international setting, things change dramatically, and differently from what was described in the three-individual examples above. International relationships can be sketched by two extreme profiles. Let A and B denote the two countries under consideration, whose relationships are open to both real exchanges and monetary exchanges. In this open market setting, competition does not concern only A's and B's enterprises, but also the government debt of $\mathrm{A}$ and $\mathrm{B}$, which have to sell their bonds. Let us imagine that A's savers find bonds offered by B more palatable and accordingly they buy B's bonds. Assuming an extreme case, all A's savers, or most of them, could buy bonds issued by B's government. This is a likely event in a democratic state where savers maximize their expected results and where the cooperative state presuppositions cannot be applied. By subscribing B's bonds, it is as if A's savers wanted to punish their government, as a sort of voting with their feet. However, a punishment on A's government is not equal to a punishment on A's future generation. And in fact, a punishment on government may generate an advantage for A's future generation. Even in the extreme case in which A's government may default, the future generation could survive thanks to the accrued interest on B's bonds owned by A's savers. This point is an interesting one because it shows the limits of a position à la Barro where pure altruism allows insulating government from international competition.

Mutatis mutandis, we would have the same scenario if B's savers did not trust their government and bought A's bonds. On the whole, the two alternatives are able to show not only the limits of Barro's altruism, but also the difficulty that one encounters by extending the presuppositions of the cooperative state to a democratic setting.

The relevance of the distinction between internal debt and external debt, based on the aphorism 'we owe it to ourselves', heralded by Abba Lerner (1943, 1944), has been under vigorous attack by Buchanan (1958), who claims that such a distinction is of a marginal kind since it is contingent on the institutional setting. In particular, Buchanan clarifies that resorting to an external debt allows a larger national gross income, but once interest is deducted, net national income is the same in the two cases. Buchanan's stance is central for also clarifying de Viti's analysis. International indebt- 
edness turns de Viti's governments from intermediaries of producers' and consumers' cooperatives into competitive governments, as political enterprises maximizing their own interests. Thinking of canceling competition between or among governments in order to extend the cooperative model to international relationships is, conversely, to give rise to collusive relationships where governments are not agents of taxpayers, but rather interest groups.

A further clarification is needed here. Intergovernmental competition on available savings makes evident how the aphorism 'we owe it to ourselves' hides competition and ends up by considering the whole debt as it were an internal debt. Differently from de Viti, to whom debt extinction may result from a generalization or democratization process, Abba Lerner conceives of debt as self-extinguished from birth. Hence public debt will never be a problem. To de Viti, in contrast, public debt can generate problems of the form he associated with economic crises (see de Viti, 1898). In framing debt within the general theory of crisis, de Viti emphasizes the evaluation mistakes made by the previous generation. But there is a second aspect in de Viti's thought, which we think is more general, that has been ignored by the literature. This aspect is linked to the change in preferences over time and to the lack of a price mechanism able to quickly capture the disequilibrium between demand and supply, of which the crisis is the result. Debt and crisis intertwine and do not self-extinguish, and may instead lead to default.

\section{DEMOCRATIC STATE DEFAULT WITH INTERNAL DEBT}

The relevant officials within a government that shifts from tax finance to loan finance must have concluded that loan finance is less costly from their perspective than tax finance. This might well induce those officials to support expansions in spending that are wasteful when compared to the displaced private alternative activities. If indebtedness were forbidden, those wasteful expenditures would not have occurred. De Viti observes that if this logic regarding public loans were applied to the private loan system, an excessive demand for loans would result because entrepreneurs would not bear personal liability for their losses. This situation is actually not all that far-fetched in contemporary times where many private businesses receive political support and largesse through loan guarantees and subsidies. In numerous ways these days, a good deal of public debt finds its way into the support of nominally private enterprises.

Where de Viti's model of the cooperative state assumes a deep-level 
homogeneity among the members of the internal polity, de Viti also recognized that actual democratic polities contain no such homogeneity. Hence, there are numerous margins along which public debt can be used to transfer tax burdens from what would have resulted from an extraordinary tax. With respect to taxation, de Viti developed his model of the cooperative state under the presumption that public expenditures were normally financed by a flat tax on income. The basis on which de Viti made this assumption was that the demand for public outputs probably varied in proportion to income. While the relation between income and demand is ultimately an empirical proposition that can be subject to examination, we shall simply accept it here because our interest lies in explaining de Viti's thinking and not in examining the accuracy or plausibility of his assumptions. In consequence, we can assume that what de Viti has in mind by way of extraordinary taxation is a surtax imposed on a pre-existing flat tax. For instance, an ordinary flat rate of 10 percent might be increased to 15 percent through the addition of the extraordinary component of the tax.

If there were no public borrowing, it is reasonable to think, as did de Viti, that some people would discharge the extraordinary component of their tax liability by drawing down their balances on other assets, including cash. Other people would just as surely borrow through private credit channels. In any event, total government revenues would increase through the extraordinary tax, regardless of the extent to which those revenues came from sales of privately held assets relative to privately arranged loans. Whatever the mix, public involvement would be limited to the collection of increased taxes, along with expenditure of those tax revenues. We might further stipulate, in keeping with the tenets of de Viti's cooperative state model, that this fiscal operation is agreeable to everyone. There would be no public debt, and the private debt induced by the extraordinary tax would be self-extinguishing.

Alternatively, suppose that a public loan is issued to finance the added public expenditure. In the previous situation, a set of contractual obligations is created between a set of private lenders and those taxpayers who choose to pay their extraordinary tax by borrowing rather than by selling off other assets. When public debt is created, a governmental entity replaces the set of private creditors. Is this replacement a matter of indifference, or might it have significant consequences? There is good reason to think it will have significant consequences, and in a way that represents a form of debt default. To be sure, default is not limited to some repudiation of existing debt instruments. That is but one manner of default. Within the framework of the cooperative state, default pertains to any operation through which public debt influences individual net worth, regardless 
of what might happen to some aggregate measure of net worth, for it is individual positions and not aggregate measures that induce action.

Earlier we explained that default on external debt could generate an increase in net worth for internal citizens. It's also possible for internal debt to redistribute wealth among citizens, in which case those who gain through the issue of debt are repudiating their obligations to those who lose from the issue of debt. In this instance, the baseline for judging whether default has occurred is the set of contractual terms that would have arisen within the framework of the cooperative state. Those terms would surely have mirrored the credit market terms that would have emerged when some taxpayers choose to arrange private loans rather than sell other assets. Is it reasonable or plausible to perform the conceptual experiment of replacing a set of private loans with a politically administered loan program, and conclude in Ricardian fashion that nothing of any significance has changed? As an act of creative imagination, anything is always imaginable. As an exercise in plausible reasoning (Polya, 1954), however, it strains all credulity to assert that the replacement of a network of market loans with public debt will have no other effect than to induce changes in individual balance sheets, with some taxpayers incurring a future liability while other taxpayers reduce their present asset holdings.

The officials who guide the activities of democratic entities are not residual claimants to their activities. A private lender who mismanages the portfolio he manages will suffer a decline in net worth, and could even become insolvent and file for bankruptcy. This outcome is impossible for democratic entities. Mismanagement is obviously possible, but it manifests itself as a cost to taxpayers and not as a cost to enterprise managers, reflecting Wagner's (2016) recognition that politics is a peculiar and not an ordinary form of business activity. Furthermore, democratic polities are riven with margins of heterogeneity whereby gains to some people entail losses to others. For instance, de Viti thought in terms of a flat rate of tax on all income. Contemporary tax systems, however, exempt a great deal of income from the tax base. Within the United States, for instance, roughly half the adult population is exempt from the federal income tax. To the extent that borrowing enables an increase in public expenditure within what is clearly a semi-cooperative democracy, debt-financed expenditure will to some extent be self-repudiating and not self-extinguishing.

\section{A SIDEBAR REMARK ON CAPITAL BUDGETING}

Fiscal and budgetary scholars often distinguish between current and capital budgeting. The central idea in advancing this distinction is to create a 
separation between those objects of expenditure that are used up during the current year and those that provide service over several years. The capital budgeting idea would place what are judged to be capital expenditures into separate accounts that are amortized over some suitable number of years. Each year, the appropriate amount for amortization would be transferred to the current budget. Within this budgetary format, current spending would be financed by taxation and capital spending would be financed by public debt. Capital budgeting is often practiced by corporations, and the extension of capital budgeting to governments would seem to be little more than the extension of good business practices to governments.

Once it is recognized that government are peculiar forms of business (Wagner, 2016), capital budgeting can easily be misused. The institutional arrangements by which commercial corporations are governed render them as instances of cooperative collectivities in de Viti's sense. This is not the case with democratic polities. Suppose the capital budgeting idea is inserted into a democratic political constitution. The first issue that must be faced is how to distinguish between current and capital expenditures. Not far behind making this distinction is the need to determine the period of time over which capital expenditures will be amortized. Also to be determined is the locus of responsibility and capacity for making these determinations. In modern, large-scale polities, we may be sure that such determinations will not be made by some such abstract notion of 'the citizenry'. They will be made by bureaucratic officials and legislators and in an environment where knowledge is concentrated among intensely interested insiders to the activities in question.

To illustrate in stark relief the problem of inherent ambiguity that capital budgeting entails in democratic polities, consider an agency that is confined by a balanced budget requirement when the head of the agency would like to take his managerial staff on a week-long retreat in some remote venue. The balanced budget requirement would prevent this activity. Such activity might, however, pass muster in the presence of capital budgeting. What would be necessary is to classify the retreat as an investment in enhancing future performance. In this respect, it could be claimed that it is necessary to gain emotional distance from daily organizational activities for management to be able calmly and systematically to evaluate approaches to agency reorganization that would improve future performance. What is in play, then, is a claim that such a current expenditure should be classified as a capital item, so should be incorporated into a capital budget, with the expense amortized over some period of years. While this example might seem a bit far-fetched, it points all the same to recognition that the distinction between current and capital expenditures contains unavoidable margins of arbitrariness. In light of those unavoid- 
able margins of ambiguity, political officials will have margins of action along which they can classify actions to promote their desires.

\section{CONCLUDING REMARKS}

Although in democracy government plays an intermediary role, this intermediation is different from that developed in de Viti's cooperative model. In a democratic model, taxpayers and subscribers are not the same and government intermediation is a process that interconnects a share of the population (taxpayers) with another share (subscribers). As we have already seen, while in a cooperative model taxpayers and subscribers are the same individuals, it is not so in the democratic model and also in the case of external public debt. The latter two cases lead us to conclude that there isn't any automatic extinction of the debt. Contrary to the pre-democratic model, where the sovereign debt was a personal debt, ${ }^{6}$ in the democratic model, where the parliamentary assembly creates public debt in the name and on behalf of taxpayers, public debt also raises ethical issues. While the Ricardian equivalence theorem is not a good fit for the democratic model, de Viti's non-equivalence theorem is a good fit because it also incorporates the expenditure side into his model. De Viti does not conceive of public debt as an ordinary rational problem, for he associates public debt with extraordinary economic crisis. Thus, economic crisis raises intertemporal and not intergenerational issues because public debt is not shifted to future generations. But we believe that the economic crisis/ debt is at once de Viti's strong point and his Achilles heel. The crisis, in fact, is not so much the result of an intentional project of transferring costs to future generations as it is the inexorable outcome of politically directed choices inside institutional arrangements that escape the confines of the cooperative state.

To de Viti, the economic crisis has, in fact, its origin in a wrong evaluation of the investments that have yielded lower levels of benefits than expected. However, this is only part of the story. De Viti conceives of the crisis as a failure in investments presuming that all public expenditures financed through debt are employed in investments without considering that the government has a proclivity to wasteful expenditures, for it is guided by the conviction that public debt is less costly than an extraordinary tax and even an ordinary tax.

6 On this see Eusepi and Wagner (2012). 


\section{REFERENCES}

Barro, R. (1974), 'Are government bonds net worth?', Journal of Political Economy, 82: 1095-118.

Buchanan, J.M. (1958), Public Principles of Public Debt, Homewood: Richard D. Irwin.

Buchanan, J.M. (1960), "La scienza delle finanze": The Italian tradition in fiscal theory', in J.M. Buchanan, Fiscal Theory and Political Economy: Selected Essays, Chapel Hill: The University of North Carolina Press.

Buchanan, J.M. (1976), 'Barro on the Ricardian equivalence theorem', Journal of Political Economy, 84: 337-42, pp. 24-74.

De Viti de Marco, A. (1888), Il Carattere Teorico dell'Economia Finanziaria, Rome: Pasqualucci.

De Viti de Marco, A. (1893), 'La pressione tributaria dell'imposta e del prestito', Giornale degli Economisti, 6 (2) (January-March): 38-67, 216-31.

De Viti de Marco, A. (1898), 'Contributo alla teoria del prestito pubblico', in Saggi di Economia e Finanza, Rome: Giornale degli Economisti, pp. 61-123.

De Viti de Marco, A. (1930), Un Trentennio di Lotte Politiche, Rome: Collezione Meridionale Editrice.

De Viti de Marco, A. (1936), First Principles of Public Finance, London: Jonathan Cape.

Eusepi, G. (1989), 'Buchanan's critique of the neoclassical model and the rediscovery of the Italian tradition in public finance', Rivista Internazionale di Scienze Economiche e Commerciali, 36 (9): 801-22.

Eusepi, G. and R.E. Wagner (2012), 'Indebted state versus intermediary state: Who owes what to whom?', Constitutional Political Economy, 23: 199-212.

Giuranno, M. and M. Mosca (2016), 'Political realism and models of the state: Antonio de Viti de Marco and the origins of public choice', working paper, Dipartimento di Scienze dell'Economia, Università del Salento.

Griziotti, B. (1917), 'La diversa pressione del prestito e dell'imposta', Giornale degli Economisti e Rivista di Statistica, 54 (3): 313-34.

Lerner, A.P. (1943), 'Functional finance and the federal debt', Social Research, 10: $38-51$.

Lerner, A.P. (1944), The Economics of Control, New York: Macmillan.

Polya, G. (1954), Mathematics and Plausible Reasoning, 2 vols, Princeton: Princeton University Press.

Ricardo, D. (1817 [1951]), The Principles of Political Economy and Taxation, Cambridge: Cambridge University Press.

Roth, T.P. (2002), The Ethics and the Economics of Minimalist Government, Cheltenham, UK and Northampton, MA, USA: Edward Elgar Publishing.

Schmitt, C. (1932) [1996]), The Autonomy of the Political, Chicago: University of Chicago Press.

Wagner, R.E. (2016), Politics as a Peculiar Business: Insights from a Theory of Entangled Political Economy, Cheltenham, UK and Northampton, MA, USA: Edward Elgar Publishing. 